South African Journal of Animal Science 2021, 51 (No. 3)

\title{
A review of artisanal cheese making: An African perspective
}

\author{
F. Nyamakwere, G. Esposito, K. Dzama \& E. Raffrenato \\ Department of Animal Sciences, Faculty of Agricultural Sciences, University of Stellenbosch, South Africa
}

(Submitted 14 March 2020; Accepted 15 March 2021; Published 30 April 2021)

\begin{abstract}
Copyright resides with the authors in terms of the Creative Commons Attribution 4.0 South African Licence.
See: http://creativecommons.org/licenses/by/4.0/za

Condition of use: The user may copy, distribute, transmit and adapt the work, but must recognize the authors and the South African Journal of Animal Science.
\end{abstract}

\begin{abstract}
Artisanal cheeses and other fermented milk products have long been part of the diet of African rural communities. Cheese is a source of nutrients that are essential to the development and growth of children in rural areas, where intake of amino acids, vitamin $A$, vitamin $B_{12}$, calcium, phosphate, and polyunsaturated fatty acids may be limited. Wara, Karish, Ayib, Takammart, Wagashi, Domiati, and Ras are prominent cheeses of African origin. Artisanal cheese making should be expanded to improve people's nutritional status at low cost, stimulate the local economy, and empower small-scale farmers. This review firstly gives an overview of artisanal cheese production and consumption, and evaluates opportunities and challenges, while focusing on an African perspective. Secondly, it provides an insight into strategies that could improve cheese making at small-scale level. Possible areas of research and knowledge gaps are highlighted, particularly ways of improving cheese quality and safety.
\end{abstract}

\footnotetext{
Keywords: cheese quality, fermented products, nutritional qualities, raw milk

"Corresponding author: emiliano@sun.ac.za
}

In 2018, total cow milk cheese production in Africa was 405098 tonnes, which is only $2.1 \%$ of world average production. Most of this production was from Egypt (274 800 tonnes), South Africa (53 949 tonnes), South Sudan (30 965 tonnes), Tanzania (16 678 tonnes), Zambia (6 022 tonnes), and Ethiopia (5 033 tonnes). Milk production has increased worldwide, and it is projected to continue to increase $1.6 \%$ per annum to $997 \mathrm{Mt}$ by 2029 (OECD-FAO, 2020). As a consequence, the production of dairy products such as cheese, butter, and whole and skim milk powders is expected to increase, creating new markets for these products (OECD-FAO, 2015). However, production and per capita consumption of milk and cheese are higher in developed countries than in developing ones (Mikkelsen, 2014). But this gap is reported to be narrowing because of population growth, dynamic economic developments, urbanization, income increase, and changing eating habits and lifestyle (Ndambi \& Hemme, 2009; OECD-FAO, 2015). There is a shift in the structure of people's diets towards value-added dairy products such as cheese (Ronquest et al., 2015). This is having a positive influence on the growth of artisanal cheese markets (Mulder \& Wasserfall, 2013; Mikkelsen, 2014). Generally, in Africa, milk constitutes an important part of rural peoples' diet and is consumed fresh and processed at the household level (Gadaga et al., 1999; Nzigamasabo \& Nimpagaritse, 2009; Abdelgadir et al., 2001). Fermentation is one of the oldest effective and inexpensive food preservation technologies that help in milk preservation and improve nutritional and sensory properties (O'Connor, 1993). There are many fermented artisanal milk products and consumption varies significantly among countries and regions because of social and cultural circumstances.

In African rural households, naturally soured milk is one of the most common fermented dairy products (Gadaga et al., 1999). The sour milk is processed with traditional equipment and techniques according to the culture and region of origin (Gadaga et al., 1999; Nzigamasabo \& Nimpagaritse 2009; Abdelgadir et al., 2001; Beukes et al., 2001). In Zimbabwe, sour milk (mukaka wakakora) is processed at household level by leaving the fresh raw milk to ferment naturally at ambient temperature, mostly in earthenware pots, for 1 - 3 days and at times whey from previous batches can be added to speed up the fermentation process (Gadaga et al., 1999). Similarly, Urubu a sour milk product from Sudan is processed using the same technique in earthenware containers (Aloys \& Angeline, 2009). A slightly different technique is used for Rob, a fermented milk product from Sudan which is initiated by adding a starter from the fermentation of the previous day and 
left overnight (Abdelgadir et al., 2001). The milk is then churned after 24 hours in a leather container or a gourd from the Lagenaria leucantha plant. It is consumed as a drink or used for sauce making (Abdelgadir et al., 2001). In some regions, sour milk is processed to products that resemble yoghurt and fresh cottage cheese (Gadaga et al., 1999; Nzigamasabo \& Nimpagaritse, 2009), with butter as a by-product (Abdelgadir et al., 2001). However, the main challenge with these products in rural communities is their short shelf-life of two to three days. Thus, they cannot be stored for supplementation during lower milk production seasons. Processing of dairy products with a longer shelf-life, such as long-aged artisanal cheese types, therefore, assumes greater importance. Because cheese is a good source of essential amino acids, vitamin A, vitamin $\mathrm{B}_{12}$, calcium, phosphate, and beneficial polyunsaturated fatty acids (López-Expósito et al., 2012; Jerónimo \& Malcata, 2016), this is an ideal way of preserving milk nutrients and helps fight malnutrition in vulnerable communities.

The overemphasis on economic challenges to small-scale farmers often overshadows the debate about potentiality of artisanal cheeses, which can be processed using local resources, with low input of ingredients and machinery (McSweeney et al., 2004; Omemu et al., 2014; Ombarak et al., 2016). There is a need to evaluate the processing of artisanal cheeses in rural areas with appropriate economic approaches that consider the local people's social-economic status, culture, and region. Strategies that could improve farmers' productivity include technical training, indigenous knowledge development, mentorship, financial support and working as cooperatives. Cornelisse and Hyde (2017) highlighted that processing of valueadded products, such as cheese, by small-scale farmers guaranteed a better income than the sale of raw milk. Fermented dairy products have been processed for years at household level and most of these skills have been modified and commercialized to meet the demands of people who moved to urban communities (Gadaga et al., 1999; Beukes et al., 2001). Projects aimed at rebuilding these practices in rural communities could improve people's nutritional status and income. The objectives of this review are i) to give an African perspective of artisanal cheese production and consumption, ii) to evaluate opportunities and challenges of artisanal cheese processing in rural areas, and iii) to provide insight into strategies to improve cheese making at small-scale level.

In this review the term 'traditional' is used to refer to cheese produced in a defined geographical area using specific know-how and skills, with little or no prior processing of the milk (Montel et al., 2014). 'Artisanal' refers to products that are handmade in a customary way with little mechanization (Blundel, 2017). Processing techniques and recipes are passed from generation to generation through practical experience and observation (O'Connor, 1993). Over the years, cheeses have been processed with milk from species such as sheep, goats, buffalo, camel and cattle, but cattle have become the dominant dairy species around the world (Fox \& McSweeney, 2004). In developing nations, cheese production and consumption are projected to continue to increase (Figure 1). Interestingly, the numbers show that production volumes are far lower than consumption, thus more needs to be done to meet the projected demand.

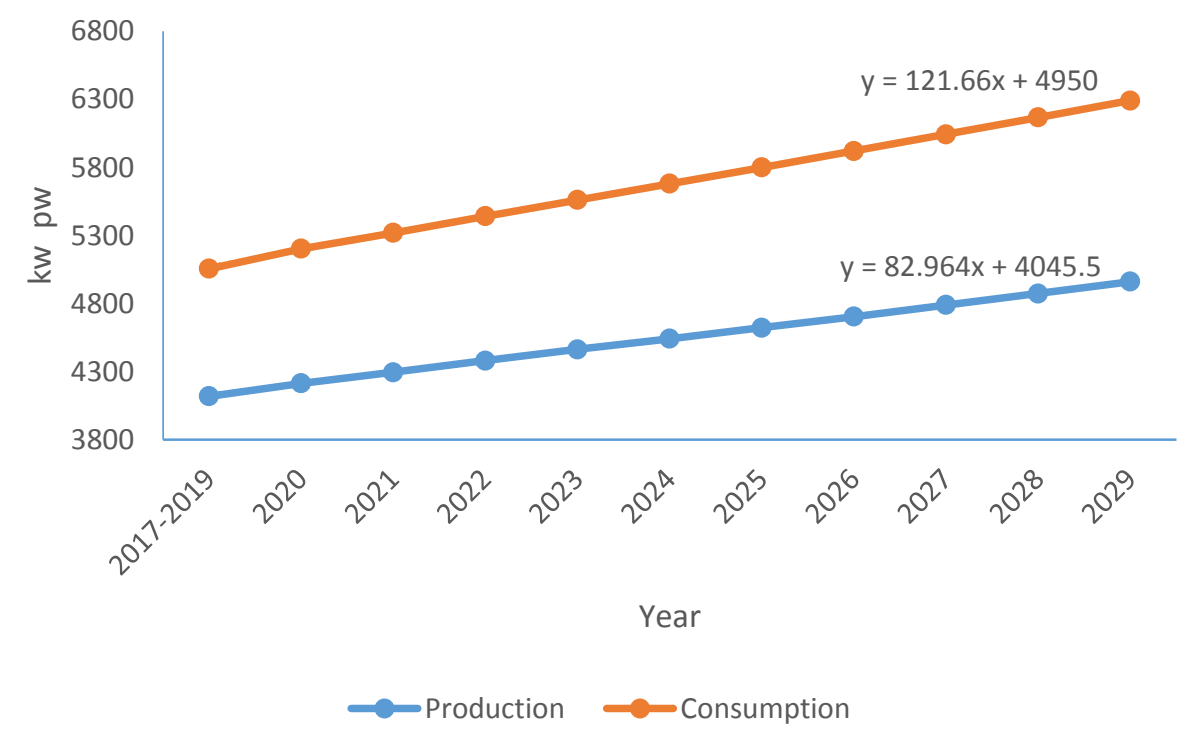

Figure 1 Projected trends of cheese production and consumption in developing nations (OECD-FAO, 2020) 
The main steps in making cheese are acidifying, coagulating, separating curds and whey, salting, moulding, and ageing (Fox \& McSweeney, 2004). Briefly, raw milk is heated to $37^{\circ} \mathrm{C}$ and starter cultures such as Lactobacillus delbrueckii ssp. lactis and Streptococcus thermophilus are added to aid acidification (McSweeney et al., 2004). The lactic acid dissolves the calcium phosphate from the micelles and aggregation influences the formation of a protein network (Lundin et al., 2015). The milk is then coagulated with an animal or plant rennet. The enzymes eliminate the casein macropeptide from k-casein, and paracasein micelles start to aggregate, forming firm curds (Lundin et al., 2015). The curds are then cut and packed in moulds to facilitate whey drainage and give a specific shape. After draining, the cheese blocks are salted using the dry salting technique or a solution ( $\mathrm{NaCl}$ ). Salt helps to develop flavour (Smit et al., 2001), makes the curd firmer, and inhibits bacterial contamination (Atasoy, 2008). Fresh cheeses such as ricotta can be consumed after a few hours of cooling and whey drainage, whereas semi-hard and hard cheeses require weeks and months of ageing (Fox \& McSweeney, 2004).

Demand and preference for cheese products differ from region to region and shifts have tended towards more natural and less processed artisanal products, with markets being affected by healthconscious consumers (Claeys et al., 2013). The range of cheese types manufactured in different regions varies significantly because of processing technologies and social and cultural traits. Richer households in urban areas of Kenya consume significantly more milk and cheese than poor households, suggesting that consumption is related to income and availability (Njarui et al., 2011). For the past few decades, cheese has penetrated bigger markets in most developing countries as an ingredient of fast foods such as pizza and burgers (Mikkelsen, 2014), and because of economic developments, changing eating habits, and increased availability (Ndambi \& Hemme, 2009; OECD-FAO, 2015).

Keeping livestock and producing on-farm fermented milk products have long traditions in eastern and southern Africa (Franz et al., 2014). In most sub-Saharan countries, on-farm cheese production and consumption are low, except for Sudan and Ethiopia, where there is a long tradition for fresh cheeses made at farm level (Mikkelsen, 2014). In South Africa, most cheeses have English, Italian, Dutch, French and Swedish origins (Mulder \& Wasserfall, 2013), with Cheddar holding a greater share $(31 \%)$ of the market, followed by Gouda (20\%), and Mozzarella (Ronquest et al., 2015). However, a few on-farm artisanal producers make cheeses such as Karoo Crumble, Ganzvlei Vastrap, Ficksburger, and Huguenot. There are limited scientific studies of the production, physicochemical and sensory properties of these cheeses.

Products that resemble cottage cheese are produced traditionally at household level in Ethiopia and Zimbabwe and are known as Ayib and Mukaka wakakodzekwa or Hodzeko, respectively (Gadaga et al., 1999). Hodzeko involves pooling fermented milk from three successive days, from which whey and cream have been removed (Gadaga et al., 1999).

Most of the predominant artisanal cheeses in East Africa and northern Africa are soft and are consumed fresh without ripening or are ripened for a few days (Table 1) and thus have a limited shelf-life. For example, Wara, which is produced and consumed as an important protein source in West African regions, has a shelf-life of two to three days (Adetunji et al., 2008). For a longer shelf-life, cheeses can be preserved with techniques such as salting, smoking, drying, and adding natural preservatives. Lemon juice is used as a coagulant and a preservative in Wara cheese manufacture and reduces its Enterobacteriaceae counts significantly (Adetunji et al., 2008).

In southern Algeria and Niger, hard cheeses that are sun dried are common and have a longer shelflife of about three to six months (O'Connor, 1993). In addition to preservation, appearance is an important sensory attribute for consumers. The appearance of artisanal cheeses can be enhanced by coating them with vegetables and oils. For example, in Benin, Wagashi cheese is coloured with a hot solution of red sorghum (Sorghum bicolor) leaves and stems. These techniques give artisanal cheeses their authentic flavours, texture and unique sensory properties (Montel et al., 2014). In addition, the distinct characteristics may be the result of factors such as milk chemical composition, local conditions, and processing skills and experience (Serhan et al., 2010; Niro et al., 2014).

Although in Africa the consumption of cheese and demand for cheese with specific characteristics is limited compared with Europe, several cheeses are believed to be indigenous to Africa (O'Connor, 1993; McSweeney et al., 2004) (Table 1). These cheeses vary in the technologies that are used in producing them, such as cooking, stretching, pressing, using a starter culture, and preserving, and are consumed after various ripening periods. As a result, they express characteristics that give them their distinctiveness, which affects consumer preferences. Most cheese varieties in Table 1 are produced with raw cow milk, natural rennet, and starter cultures. 
Table 1 Prominent cheese varieties that are indigenous to Africa

\begin{tabular}{|c|c|c|c|c|c|c|c|}
\hline Name & Area of origin & Raw materials & Pasteurization & Starter culture & Characteristics & Ripening & Shelf life \\
\hline Aoules & Southern Algeria & Goat milk & No & Soured naturally & Dry hard flat cylinder & $\begin{array}{l}\text { Sun dried and rarely } \\
\text { ripened }\end{array}$ & $<7$ days \\
\hline Ayib & $\begin{array}{l}\text { Eastern Africa, } \\
\text { Ethiopia }\end{array}$ & $\begin{array}{l}\text { Sour or } \\
\text { skimmed milk }\end{array}$ & No & Soured naturally & Crumbly soft cheese & $\begin{array}{l}\text { Unripened, excess whey } \\
\text { removed by heating to } \\
75^{\circ} \mathrm{C}\end{array}$ & $\begin{array}{l}7 \text { days at } \\
4{ }^{\circ} \mathrm{C}\end{array}$ \\
\hline $\begin{array}{l}\text { Braided } \\
\text { cheese }\end{array}$ & $\begin{array}{l}\text { Mediterranean } \\
\text { Region, Sudan }\end{array}$ & $\begin{array}{l}\text { Cow, goat or } \\
\text { sheep milk }\end{array}$ & No & Rennet & $\begin{array}{l}\text { Semi-hard, braided with } \\
\text { close texture, slightly acid } \\
\text { and salty taste }\end{array}$ & Unripened & $3-6$ months \\
\hline $\begin{array}{l}\text { Country } \\
\text { cheese }\end{array}$ & Nigeria & Cow milk & No & Rennet & $\begin{array}{l}\text { Hard, yellowish, smoked } \\
\text { rind with small eyeholes, } \\
\text { slightly acid and salty taste }\end{array}$ & Several weeks at $4{ }^{\circ} \mathrm{C}$ & $\begin{array}{l}6-12 \\
\text { months }\end{array}$ \\
\hline $\begin{array}{l}\text { Fromage } \\
\text { blanc }\end{array}$ & Madagascar & Skimmed milk & Boiled for $5 \mathrm{~min}$ & Rennet & $\begin{array}{l}\text { Soft fresh cheese with no } \\
\text { rind, slightly salty }\end{array}$ & Unripened & $<7$ days \\
\hline Gibna & Sudan & $\begin{array}{l}\text { Cow, sheep } \\
\text { or goat milk or } \\
\text { mixture }\end{array}$ & No & $\begin{array}{l}\text { Natural bacteria } \\
\text { and commercial } \\
\text { rennet }\end{array}$ & $\begin{array}{l}\text { Soft white cheese, slightly } \\
\text { salty and sour and close } \\
\text { texture }\end{array}$ & Unripened & $<7$ days \\
\hline Mashanza & $\begin{array}{l}\text { Democratic } \\
\text { Republic of the } \\
\text { Congo }\end{array}$ & Cow milk & No & Natural bacteria & $\begin{array}{l}\text { Soft white and ball shaped, } \\
\text { no rind with big eyes, } \\
\text { slightly sour taste }\end{array}$ & Unripened, & $<7$ days \\
\hline $\begin{array}{l}\text { Mboreki Ya } \\
\text { Iria }\end{array}$ & Kenya & $\begin{array}{l}\text { Cow and goat } \\
\text { milk }\end{array}$ & $\begin{array}{l}\text { Boiled, cooled to } \\
\text { ambient }\end{array}$ & $\begin{array}{l}\text { No rennet or } \\
\text { enzyme added }\end{array}$ & $\begin{array}{l}\text { Soft fresh cheese, no rind, } \\
\text { slight salty and sour taste }\end{array}$ & Drained overnight & $<7$ days \\
\hline $\begin{array}{l}\text { Mudafara } \\
\text { cheese }\end{array}$ & $\begin{array}{l}\text { Middle East, } \\
\text { Sudan }\end{array}$ & Cow milk & No & $\begin{array}{l}\text { Natural bacteria } \\
\text { and rennet }\end{array}$ & $\begin{array}{l}\text { Semi-hard, no rind, slightly } \\
\text { salty taste and plaited }\end{array}$ & $\begin{array}{l}\text { Unripened, stored in brine in } \\
\text { welded tins at } 21^{\circ} \mathrm{C}\end{array}$ & 3 - 6 months \\
\hline Takammart & Southern Algeria & Goat milk & No & Kid dry abomasum & $\begin{array}{l}\text { Dry hard cheese, flat square } \\
\text { shape, dark brown in colour }\end{array}$ & $\begin{array}{l}\text { Sun dried for } 2-3 \text { days and } \\
\text { kept in shade afterwards }\end{array}$ & 3 - 6 months \\
\hline Tchoukou & Niger & $\begin{array}{l}\text { Cow, sheep, } \\
\text { goat or camel } \\
\text { milk }\end{array}$ & No & $\begin{array}{l}\text { Rennet from lamb } \\
\text { or kid's abomasum } \\
\text { or industrial }\end{array}$ & $\begin{array}{l}\text { Hard milky-white, no rind, } \\
\text { thin dry rectangle with close } \\
\text { texture, mild taste }\end{array}$ & $\begin{array}{l}\text { Sun dried, preserved in } \\
\text { aerated baskets (Aznam) } \\
\text { for } 3 \text { to } 6 \text { mnths }\end{array}$ & $\begin{array}{l}6-12 \\
\text { months }\end{array}$ \\
\hline Wagashi & $\begin{array}{l}\text { Mali, Niger, } \\
\text { Burkina Faso, } \\
\text { Ghana and } \\
\text { Mauritania }\end{array}$ & Cow milk & $\begin{array}{l}\text { Boiled for } 3 \text { to } 5 \\
\text { min }\end{array}$ & $\begin{array}{l}\text { Juice from crushed } \\
\text { Bryophyllum stems }\end{array}$ & $\begin{array}{l}\text { No rind, white with small } \\
\text { eyeholes, slightly sour and } \\
\text { salty }\end{array}$ & $\begin{array}{l}\text { Unripened, kept in brine } \\
\text { with } 25 \% \text { salt }\end{array}$ & $\begin{array}{l}3 \text { days out of } \\
\text { brine, } 14 \\
\text { days in brine }\end{array}$ \\
\hline Wagassirou & Northern Benin & Cow milk & Boiled for 1 hour & No & $\begin{array}{l}\text { Soft fresh whitish, curved } \\
\text { disk shape, close texture \& } \\
\text { slightly acid and salty }\end{array}$ & $\begin{array}{l}\text { Unripened, preserved by } \\
\text { salting, smoking or drying }\end{array}$ & 1 mnths \\
\hline Hodzeko & Zimbabwe & Cow milk & No & $\begin{array}{l}\text { Fermentation by } \\
\text { natural milk } \\
\text { microbiota }\end{array}$ & Fresh cottage cheese-like & Unripened & $<7$ days \\
\hline
\end{tabular}


Table 1 Prominent cheese varieties that are indigenous to Africa (continued)

\begin{tabular}{|c|c|c|c|c|c|c|c|}
\hline Name & Area of origin & Raw materials & Pasteurization & Starter culture & Characteristics & Ripening & Shelf life \\
\hline Ras & Egypt & $\begin{array}{l}\text { Cow and/or } \\
\text { buffalo milk }\end{array}$ & No & $\begin{array}{l}\text { Fermentation by } \\
\text { native microflora }\end{array}$ & Hard cheese & Ripened for few months & - \\
\hline Wara & Nigeria & Cow milk & $\mathrm{N}$ & $\begin{array}{l}\text { Extract of } \\
\text { Calotropis procera } \\
\text { or Carica papaya } \\
\text { leaves }\end{array}$ & Soft fresh cheese & Unripened & $\begin{array}{l}2 \text { - } 3 \text { days or } \\
4 \text { - } 5 \text { days in } \\
\text { cool water }\end{array}$ \\
\hline Karish & Egypt & $\begin{array}{l}\text { Cow or a } \\
\text { mixture of } \\
\text { cow and } \\
\text { buffalo milk }\end{array}$ & No & $\begin{array}{l}\text { Natural acid } \\
\text { coagulation }\end{array}$ & Soft fresh white cheese & Unripened & $\begin{array}{l}7 \text { - } 11 \text { days, } \\
\text { immersed in } \\
\text { whey }\end{array}$ \\
\hline Domiati & Egypt & $\begin{array}{l}\text { Cow or } \\
\text { buffalo or } \\
\text { mixture }\end{array}$ & $\begin{array}{l}\text { Raw or } \\
\text { pasteurized milk }\end{array}$ & $\begin{array}{l}\text { Rennet and starter } \\
\text { cultures are added }\end{array}$ & $\begin{array}{l}\text { Pickled soft white cheese, } \\
\text { salty }\end{array}$ & $\begin{array}{l}\text { Consumed fresh or after } \\
\text { pickling for } 4 \text { - } 8 \text { months }\end{array}$ & - \\
\hline Klila & Algeria & $\begin{array}{l}\text { Cow or sheep } \\
\text { milk }\end{array}$ & $\begin{array}{l}\text { Heated to } 55-65 \\
{ }^{\circ} \mathrm{C} \text { until whey is } \\
\text { separated }\end{array}$ & $\begin{array}{l}\text { Natural } \\
\text { fermentation for } 24 \\
\text { to } 48 \text { hours }\end{array}$ & White soft cheese & $\begin{array}{l}\text { Consumed fresh or dried in } \\
\text { open air for } 2 \text { - } 3 \text { days }\end{array}$ & $<7$ days \\
\hline $\begin{array}{l}\text { Traditional } \\
\text { Bouhezza }\end{array}$ & Eastern Algeria & $\begin{array}{l}\text { Goat, sheep, } \\
\text { cow milk or } \\
\text { mixture }\end{array}$ & No & $\begin{array}{l}\text { Natural } \\
\text { fermentation for } 24 \\
\text { to } 72 \text { hours }\end{array}$ & $\begin{array}{l}\text { Soft, smooth, and } \\
\text { spreadable texture: flavours } \\
\text { are slightly salty, spicy, and } \\
\text { acidic }\end{array}$ & $\begin{array}{l}\text { Ripened in a natural and } \\
\text { permeable goat skin bag } \\
\text { (chekoua) for } 2 \text { to } 3 \text { months }\end{array}$ & - \\
\hline Huguenot & South Africa & Cow milk & Pasteurized milk & Non-animal rennet & $\begin{array}{l}\text { Semi-hard, brushed rind } \\
\text { style moulded into huge } \\
\text { golden cartwheels, nutty } \\
\text { flavour }\end{array}$ & Minimum of 6 months & - \\
\hline
\end{tabular}

Adapted from FAO (1990), O'Connor (1993), McSweeney et al. (2004, 2017), Ramalho Ribeiro et al. (2006), Benkerroum (2013), Ibrahim et al. (2015), Benlahcen et al. $(2017)$ 
In some African regions, cheese is still produced as a farm-based operation under artisanal conditions, but information about the volume is limited. Artisanal cheeses such as Wara (Omemu et al., 2014), Ayib (O'Connor, 1993), and Karish (Ombarak et al., 2016) are produced on-farm on a small scale and mainly for family consumption or vending on the streets. Most artisanal cheese varieties are now produced in large highly mechanized factories to meet the growing demand in urban areas (Gadaga et al., 1999; Beukes et al., 2001).

Traditionally, the milk is fermented with natural native bacteria, animal rennet or plant extracts as coagulants (O'Connor, 1993; Mulder \& Wasserfall, 2013). Karish cheese from Egypt is an example of a traditionally manufactured cheese using natural native bacteria, mainly the lactic acid in raw cow or buffalo milk (Ombarak et al., 2016). The non-starter lactic acid bacteria in ripening cheese are responsible for flavour development (McSweeney et al., 2004) and are found mainly in raw milk (Terzic-Vidojevic et al., 2007). This gives artisanal cheeses a unique taste, which is not found in industrial cheeses. Kupiec and Revell (1998) noted that artisanal cheese consumers seek premium quality, uniqueness, and superiority in their food. Several studies regarding artisanal cheese sensory properties have been conducted (Awad, 2006; Hussein et al., 2016; Shams et al., 2020) and they show that their distinctive characteristics come partly because of raw material quality and processing technologies used. Traditional processing technologies are reported to give handmade cheese unique organoleptic attributes. Since production is done by hand, there is great variability in texture and flavour and little product standardization (Bemfeito et al., 2016).

In some African regions, plant extracts from papaya (Carica papaya), pineapple (Ananas comosus), lemon juice (Citrus limon), castor oil seeds (Ricinus communis), fig trees (Ficus carica) and Sodom apples (Calotropis procera) are used as coagulants (Mikkelsen, 2014; Agossou Yao et al., 2015). For example, Wara from West Africa is an unripened cheese that is coagulated with leaf extract from $C$. procera or $C$. papaya (Adetunji et al., 2008). These plant extracts contribute to the sweeter flavour. However, industrial use of these plant extracts is practically non-existent because of the associated lower cheese yields and higher bitterness compared with commercial rennet (Amira et al., 2017).

In addition, traditional cheeses can be found in colours that are unique to that variety. Prior to the use of annatto, an extract from achiote trees (Bixa Orellana) in Latin American countries and the Caribbean, in commercial factories cheese makers used vegetable dyes such as $S$. bicolor and olives (Olea europaea) to enhance the appearance (Mulder \& Wasserfall, 2013). These natural food colourants are preferred as they offer health benefits such as antioxidative and antimicrobial properties (Sharma et al., 2019).

The availability of local ingredients suggests that cheese could be produced successfully in rural communities. However, lack of standardization and poor hygiene standards present obstacles to the commercialization and export of most artisanal cheeses. To date, developments in the cheese industry include improved hygiene protocols and the use of commercial starter cultures, rennet and colourants (Johnson, 2017). These have resulted in the production of microbial safe products with a more consistent quality. Nevertheless, consumers in regions with a tradition of on-farm cheese processing favour their local products because of their nutritional benefits, palatable taste and affordability (Hammad et al., 2015).

In rural areas, livestock rearing is still important in most people's livelihoods, with milk consumption forming an important part of their diets. Livestock are regarded as a measure of wealth in these communities (Bettencourt et al., 2015). However, milk and cheese production are low, especially in developing countries (OECD-FAO, 2015). Focus must be put on greater milk and cheese production in these regions to promote and increase consumption, which depends partly on availability. South African (Kgatla \& Moremi, 2013) and Nigerian (Yunusa et al., 2012) governments tried to improve availability with schemes such as school feeding programmes with milk from local producers. These programmes promote healthy feeding for school children and support dairy farmers by creating niche markets.

Throughout history, cheese has been appreciated for its taste and benefits as a source of essential amino acids (López-Expósito et al., 2012; Jerónimo \& Malcata, 2016). Conjugated linoleic acid (CLA) has anticarcinogenic, anti-obese, antidiabetic and antihypertensive properties (Koba \& Yanagita, 2014). Tchoukou cheese, which is produced by local people in Niger, is a good source of protein, zinc and calcium (Seini et al., 2018). The high concentration of calcium in cheese contributes to the formation and maintenance of strong bones and teeth and shows a positive effect on blood pressure (Walther et al., 2008). Thus, cheese has the potential to improve people's long-term health.

The forecast increase in demand for milk and cheese products in developing countries should be harnessed by small-scale farmers to raise production and their market share. Small-scale farmers produce milk for family consumption or sell to local communities at a relatively low price. This milk could be spared for cheese making, which would result in higher profit margins for these producers. Processing value-added products gives a better income than selling raw milk (Cornelisse \& Hyde, 2017). Cheese can be processed from small quantities of milk. For example, 100 litres of milk can produce about $10 \mathrm{~kg}$ of a hard cheese (Fox et al., 2017). If farmers are not able to produce at least 50 litres of milk for cheese making, they could work 
as a cooperative. However, factors such as milk composition, the cheese-making process and time and size of curd cutting are linked to cheese yield (Janhoj \& Qvist, 2010). Cheese yield per unit of milk processed is a key factor in the profitability of an individual business, thus improving milk yield would make cheese making more economically sustainable.

In regions that produce artisanal cheeses, there has been an increase in demand because of their taste, higher nutritional value and low prices (Hammad et al., 2015). Moreover, tourists who visit African countries such as South Africa, Malawi, Mozambique, Rwanda, Uganda, and Tanzania have been reported to enjoy local cheeses (Mulder \& Wasserfall, 2013). This opens up opportunities for local dairy producers. On the other hand, farmers should be able to meet the growing demand at minimum production costs for reasonable profits. Cheese production with cheaper local resources and ingredients could be used as a model to ensure sustainability. Several reports confirmed the practice of on-farm artisanal cheese making with local resources and ingredients in countries such as Egypt (Ombarak et al., 2016), Nigeria (Omemu et al., 2014), and Algeria (McSweeney et al., 2004). Financial support should not present a major barrier to dairy farmers who want to venture into cheese making or to grow bigger to enter larger formal markets. Onfarm cheese production does not require sophisticated machinery or equipment, which are usually out of reach of most farmers. Simple equipment such as firewood, ordinary pots and cutlery is enough. Stainless steel material is recommended, whereas wood and plastic materials are not recommended as they are difficult to clean (Vazquez-Fontes et al., 2010). The milk pasteurizer is one of the largest and most expensive items of equipment for cheese processing (Bouma et al., 2014). To overcome this challenge, in countries such as Zimbabwe, small-scale dairy farmers were grouped in milk collection centres where donor-funded pasteurizers were installed (Netherlands Development Organization (SNV), 2012). Alternatively, small-scale producers could use raw milk if they maintain proper hygiene standards to produce microbiologically safe products.

Another advantage in rural communities is the ability to use family labour. This reduces costs because small-scale artisanal cheese entrepreneurs could use family labour for building, processing, and management. However, as the business grows larger, family resources, particularly land and labour, may become insufficient (Ndambi \& Hemme, 2009). Running a business as a family could be a problem because of poor planning, since a family is ruled mainly by emotions and equality, whereas a business should be economics and profit directed (Kgatla \& Moremi, 2013). Therefore, proper management and planning strategies are important to maximize production and profits. Provision of technical expertise and indigenous knowledge development would help to open opportunities for successful cheese-making enterprises.

Milk production is seasonal, which affects farmers who cannot afford to buy animal feed supplements or have effective irrigation systems for their pastures. During peak production, small-scale farmers who lack electricity and facilities to preserve the milk are at a disadvantage and are forced to sell their milk at a lower price. Furthermore, they would have too little or no milk production in the low season (Holmann, 2001). In this situation the disadvantage is double, namely loss of nutritious food and of potential income. As was seen in South Africa, small-scale farms without cooling facilities cannot compete with commercial dairy farms, or influence the milk price, which is often established by the big distributors. The development of a small-scale artisanal cheese processing factory might be the key to sustainable production. To overcome milk price competition in favour of small-scale local producers, government empowered programmes or policies could be designed and implemented effectively.

Cheese plays a significant role in many cultures and economies. In Egypt, Nigeria and Algeria there are reports of ancient and current small-scale artisanal cheese processing (Akinyosoye, 2006; Nouani et al., 2009; Ombarak et al., 2016). Indigenous or artisanal cheeses in these regions are usually vended by women at local produce markets or sold at locations such as livestock markets (Omemu et al., 2014). In Benin, the popular Peulh cheese is manufactured and sold mostly by women, while men are responsible for taking care of the animals in the fields (Kees, 1994). Cheese processing seems to open up opportunities for women empowerment, which increase income and influence over household expenditure, boosting social and economic capital. In Mozambique, Malawi, Rwanda, Uganda and Tanzania, artisanal cheese making has been reported to be a powerful tool to double family income and improve quality of life (Mulder \& Wasserfall, 2013).

An increase in household income tends to encourage the consumption of milk and dairy products (Akaichi \& Revoredo-Giha, 2014). This suggests that policies aimed at improving the income of poor people may boost their demand for dairy products and support their nutritional needs. In South Africa, demand for cheese has increased significantly because of expansion of income and urbanization (Ronquest et al., 2015), resulting in greater social impact, and growing demand for cheese and wine from local consumers and tourists (Mulder \& Wasserfall, 2013). Homemade cheese recipes are trending on national television (South African Broadcasting Cooperation), for example making ricotta with lemon juice or vinegar as coagulants. In addition, there seems to be an increase in small companies in South Africa (e.g., Finest Kind 
Plettenberg Bay, Western Cape) that offer cheese-making courses, equipment and supplies for household cheese making. This has contributed to the growth of the South African cheese industry and many producers have received prizes at international level (Mulder \& Wasserfall, 2013).

In other regions, dairy markets are reported to be changing rapidly, mainly because of increased exposure to a wider variety of food products. For example, people in Zimbabwe used to focus on making sour milk because it is consumed with their staple sadza, but now production of value-added dairy products such as cheese, yoghurt and ice cream has become popular (Brits, 2014). In Algeria, Kemaria cheese has a social impact as it is consumed at religious events such as Mawlid and Ramadan (Nouani et al., 2009). These significant social roles played by traditional cheeses and their availability in African communities guarantee their potential to be developed. However, smallholder farmers in most developing countries face challenges that make it difficult to excel in the dairy industry.

Artisanal cheese entrepreneurs lack access to economic data for developing a credible business plan to help make decisions and profits (Bouma et al., 2014, Durham et al., 2015). Common financial problems include operational costs, poor record keeping, poor profit management, incorrect pricing, over-spending and too many debts and creditors (Axtell et al., 2008). Kgatla and Moremi (2013) stated that it was difficult to convince smallholder farmers in South Africa to see dairy farming as a business because most of them did it informally. This suggested that if small-scale farmers were given access to business plans and finance they would excel in the cheese-making industry.

In African countries little work has been done to evaluate individual small-scale on-farm cheesemaking plants from the start, with close monitoring and management of production costs. More studies need to be conducted with local facilities and equipment to have affordable estimates. Estimates for start-up and production costs for a cheese plant referred to developed countries such as the USA with more highly modified technology, equipment and expensive labour (Bouma et al., 2014). Costs of dairy production must be low enough to eliminate foreign competition, and profit needs to be satisfactory so that farmers stay in business. To balance on-farm costs, producers could use whey, a by-product of cheese and casein production. Whey could be used as a nutritive animal feed supplement and producers could generate extra income by selling the product to other dairy farmers. Feeding whey on-farm improved animal water intake and provided energy, protein and minerals (El-Tanboly et al., 2017). Care must be taken when handling whey to reduce chances of contamination and whey should be introduced gradually to animals to avoid digestive disorders, which would affect productivity. Additionally, farmers should have good marketing channels for their products.

Most small-scale artisanal cheese producers have limited access to better markets (International Fund for Agriculture and Development (IFAD), 2008). Markets can be a problem when a business is established in areas with low demand for cheese or with no tradition of including cheese in daily dishes. In Zimbabwe, when Kefalos Cheese was first established, the small artisanal family business faced market-related challenges and routine power cuts. The factory was based in an area where people viewed cheese as an expensive luxury (Brits, 2014). Their milk suppliers faced infrastructure challenges, such as poor road networks. This affected their initial growth significantly, but the company now produces much of the cheese in Zimbabwe (Kagoro \& Chatiza, 2012). Small-scale and emerging producers need to be supported and well connected to commercial retailers in cities to overcome market-related challenges. Otherwise, these producers lack the technical know-how needed to be successful (FAO, 2018). Success stories include strong policy development components that allow links of small-scale dairy producers to inputs, capacity-building measures, and markets. In South Africa, the number of small-scale milk producers has decreased since 1997 because of market challenges and lack of support from authorities (Milk South Africa, 2014). When farmers have well established markets and financial guarantee, there is room for them to expand properly. However, farmers must have a more consistent milk and cheese supply. For the first few months, farmers will not receive an income from cheese making, since aged cheese is sold after at least 60 and 90 days. Nevertheless, significantly lower profits can be experienced during the dry season when milk production is lower (Holmann, 2001). In such cases, cooperative marketing would enable local small-scale producers to have a more consistent supply (Musemwa et al., 2008). In addition, producers should be involved in the dissemination of information, which plays a critical role in access to formal markets. Success would be linked to good-quality nutritious and safe products. Care must be taken during processing to maintain the physicochemical and microbiological quality of the products.

There are many potential sources of microbial contamination during artisanal cheese processing, and bacterial load levels vary significantly according to animal health, microbial metabolic potential, environmental conditions, farm practices, personal hygiene and processing conditions (Montel et al., 2014). These sources can be grouped as direct and indirect. Direct sources include the raw milk, animal teat, personnel hygiene, and dairy equipment. Indirect sources include animal feed, faeces, the milking parlour, and drinking and washing water (Montel et al., 2014). These reservoirs interact with the microbial populations 
from raw milk and starter cultures during processing, contributing to the overall microbial quality of cheese. Studies have assessed the microbiological quality of these sources (Scatassa et al., 2015; Calasso et al., 2016). Calasso et al. (2016) identified Streptococcus thermophilus, Lactobacillus casei and Lactobacillus plantarum as the most abundant bacteria on equipment used to process Caciotta and Caciocavallo Pugliese.

Milk microbiota is influenced strongly by overall farm management systems and processing conditions, which make it difficult to identify the influence of a single practice. For direct sources, teat care and sterilization of the equipment are of primary importance. Traditional cheese makers managed safety empirically by taking extra care, especially when using hand milking and wooden equipment (Montel et al., 2014). But these processes do not guarantee safe hygienic products, thus posing human health risks and limiting the commercialization and export of artisanal products. Small-scale farmers who still use such practices need to be well trained and informed about food safety (Belli et al., 2013). It is also important to monitor and maintain hygiene during ageing and storage. This is more important for producers that use raw milk, which has been reported to have bacterial populations such as E. coli, Staphylococcus aureus (Jakobsen et al., 2011) and Listeria monocytogenes (Fox et al., 2011; Lahou \& Uyttendaele, 2017). Raw milk cheeses should not have E. coli, coliforms and aerobic colony counts that exceed 2.0, 4.0 and 7.0 $\log _{10} \mathrm{CFU} / \mathrm{g}$ (Commission Regulation, 2005). Salmonella, Staphylococcal enterotoxins, and Listeria monocytogenes should not be present in a $25 \mathrm{~g}$ sample.

Small-scale processing plants usually apply improper hygiene processing procedures, which can lead to microbial spoilage of milk and dairy products (Belli et al., 2013). Unhygienic practices were reported during handling and processing of Wara cheese in Nigeria, resulting in higher counts of pathogenic bacteria (Omemu et al., 2014). Heating treatments such as pasteurization are commonly applied to the milk used in cheese-making to reduce or eliminate the risk of food poisoning, but may result in loss of authenticity in taste, aroma, flavour, and texture (Cilliers et al., 2014). Besides making the milk safe for consumption and increasing shelf-life, Cilliers et al. (2014) found that heat treatment could result in changes in the nutritional value. Claeys et al. (2013) postulated that heat treatment resulted in negligible changes in essential amino acids, vitamins, and minerals of raw milk, but concluded that consumption of raw milk posed a realistic health threat because of possible contamination from human pathogens, and recommended heating milk before consumption.

Table 2 gives a detailed list of the prevalence of pathogenic bacteria in prominent artisanal cheeses sampled from retail shops and production factories across Africa. In addition, higher levels of Enterococcus spp (Hammad et al., 2015) and E. coli (Ombarak et al., 2016) were reported in artisanal raw milk Karish cheese. Fox et al. (2011) noted that about $80 \%$ of selected farmhouse cheese-making facilities had samples (cheese, raw milk, processing, and external environment) that were positive for $L$. monocytogenes. Table 2 shows a higher prevalence of Enterobacteriaceae, E. coli and S. aureus, with a wide variation in numbers across studies. These variations can be attributed to factors such as milk quality and hygiene implementation during manufacturing, packaging, and handling (Belli et al., 2013; Laba et al., 2015). Precautions must be taken to improve hygiene and manufacturing techniques. This would help to improve domestic public health and enhance opportunities for international trade.

Best strategies for improving dairy farming lie in improved farmer education and engagement in training programmes for dairy product processing (FAO, 2018). These programmes should incorporate indigenous knowledge. Education could encourage farmers to work as cooperatives. This would help farmers who are struggling to produce enough milk for cheese making. Similar milk collection centres work well in Zimbabwe (SNV, 2012). Cooperation projects could expand internal market and export opportunities for African dairy products (Mattiello et al., 2018). Agricultural cooperatives for cheese production could enable farmers to improve the product and quality of service and reduce risks. But small-scale milk production is characterized by low productivity because of genetic and nutritional constraints (Khan et al., 2009). These affect cheese yields significantly. Therefore, general animal management schemes to improve productivity are important tools to help small-scale dairy farmers. These include animal nutrition in the form of feed and concentrates and pasture management to improve feed intake, milk yield and cheese products. Feed management should be improved so that animals are able to express their genetic superiority. The use of natural grazing and supplements rich in oils is one of the best and cheapest strategies to modify the milk fatty acid profile, resulting in cheese with higher $\alpha$-linolenic acid and beneficial isomers of CLA and antioxidants compared with conventional production (Butler et al., 2011).

Breeds play a significant role in animal performance and the quality of dairy products. Most communal and emerging farmers in South Africa use local cattle breeds such as Nguni and Afrikaner for dairy farming (Grobler et al., 2008). Although these breeds are well adapted to the harsh local environment (Scholtz et al., 2010), they are seldom suitable for dairy farming because of lower milk production compared with established dairy breeds such as the Jersey and Holstein. Muchenje et al. (2007) noted that smallholder milk production 
Table 2 The prevalence of pathogenic bacteria in some prominent artisanal cheeses from selected African countries

\begin{tabular}{lllcll}
\hline Cheese type & Pathogen & Country & No of samples \% positive samples & Reference \\
\hline Ras & Enterobacteriaceae & Egypt & 60 & 51.7 & Nosir et al., 2014 \\
Karish & Enterobacteriaceae & Egypt & 60 & 100 & Nosir et al., 2014 \\
Mudaffara & Coliform & Sudan & 54 & $>50.0$ & Abdalla et al., 2013 \\
Ras & E. coli & Egypt & 60 & 21.7 & Ombarak et al., 2016 \\
Karish & E. coli & Egypt & 55 & 74.5 & Ombarak et al., 2016 \\
Artisanal Mozzarella & E. coli & Cameroon & 42 & $>50.0$ & Belli et al., 2013 \\
Wara & E. coli & Nigeria & 45 & 72.0 & Laba et al., 2015 \\
Wagashi & E. coli O157:H7 & Ghana & 17 & 5.9 & Kunadua et al., 2018 \\
Domiati & E. coli O157 & Egypt & 50 & 4.0 & Ibrahim et al., 2015. \\
Klila & Salmonella & Algeria & 8 & 0.0 & Benlahcen et al., 2017 \\
Cottage cheese & Salmonella & Ethiopia & Unknown & 0.0 & Ejo et al., 2016 \\
Gibna & Salmonella & Sudan & 24 & 0.0 & Omer et al., 2007 \\
Tchoukou & Salmonella spp & Niger & 13 & 0.0 & Seini et al., 2018 \\
Domiati & Salmonella spp & Egypt & 50 & 4.0 & Ibrahim et al., 2015. \\
Wagashi & S. enterica & Ghana & 17 & 17.7 & Kunadua et al., 2018 \\
Wara & Salmonella typhimurium & Nigeria & 45 & 10.0 & Laba et al., 2015 \\
Klila & S. aureus & Algeria & 8 & 0.0 & Benlahcen et al., 2017 \\
Hodzeko & S. aureus & Zimbabwe & Unknown & 19.0 & Chimuti et al., 2016 \\
Gibna & S. aureus & Sudan & 24 & 79.2 & Omer et al., 2007 \\
Hodzeko & Bacillus cereus & Zimbabwe & Unknown & 2.8 & Chimuti et al., 2016 \\
Ayib & Listeria spp & Ethiopia & 100 & 4.0 & Gebretsadik et al., 2011 \\
& & & & & \\
\hline & & & &
\end{tabular}

could be improved by using Jersey and Tuli $F_{2}$ crosses. On the other hand, yield efficiency of cheese making comes from the use of milk with higher protein content and is achieved mainly through the promotion of cross breeds (Holmann, 2001), which would improve productivity and not through the introduction of established dairy breeds in African communities. The use of local breeds in extensive systems could promote the production of natural products and reduce the problem of protein intake in communities. The local cheese produced from three Nigerian cattle breeds (White Fulani, Muturu, and Red Borori) was noted as a good source of protein with good sensory properties that were acceptable to consumers (Yunusa, 2011). However, the main problem with these local breeds is low milk yield under low-input production systems (Muchenje et al., 2007; Mapekula et al., 2011). But farmers could use cooperative marketing to meet the higher volumes required for cheese production using local breeds (Musemwa et al., 2008). Mapiye et al. (2007) concluded that in future group marketing and organic certification could result in higher profit margins for small-scale dairy producers. Feed supplementation with grown mixed crop silage improved milk yield (Muchenje et al., 2007). However, the development of local dairy processing industries still needs a great deal of attention to improve the viability and sustainability of the sector.

In cheese production, the retail price, production scale and cheese type determine profit margins (Durham et al., 2015). New producers should start by manufacturing cheese types that have lower production costs. Durham et al. (2015) suggested fresh high moisture cheeses, such as Mozzarella, have lower costs of production and can be sold faster at lower prices thus helping with cash flow. Aged cheeses require an additional investment for ageing space, making the payback period longer. In some regions, for example Ragusa (Italy), local producers transport their cheeses to a central ageing centre. The owner of the centre pays the farmers for fresh cheese and takes all the risk of ageing and selling (Licitra et al., 1998). Besides helping to market the product, ageing cheese in the same environment produces more consistent and unique products specific to that area. Good-quality products are easier to market and build a stronger customer base to help grow internationally. 
Small-scale cheese producers should use good marketing strategies including the use of social media to open market opportunities for their local products. The product information should be packaged in accessible and user-friendly forms (Musemwa et al., 2008). This would improve sales and reach all classes of consumers. For example, the goat cheese from Jamtland was labelled 'local cheese' with a red heart, which marketed the product effectively in Sweden, although it was more expensive than industrial cheeses (Eriksson \& Bull, 2017). The labels 'local' and 'small-scale' imply that the product is genuine, produced with care, and has local identity. Similarly, Kefalos Cheese rebranded many of its products and motivated people to buy 'Proudly Zimbabwean' (Brits, 2014).

\section{Conclusion}

The potential for expansion of the dairy sector through artisanal cheese making with small-scale farmers is significant. It is an opportunity for African communities to fight malnutrition and meet the nutritional requirements of people in rural areas at low cost. Artisanal value-added products are attractive because they would find a market for so-called natural products. Small-scale farmers fit this market well because consumers tend to favour local products as they are viewed as having local identities, possessing favourable sensory properties, and as being affordable. Lack of economic information and knowledge pose barriers to entry into small-scale artisanal cheese production. More research should focus on designing a cheesemaking model for small-scale producers and disseminating the information properly. Although the farmers might face challenges, if supported with proper technical training and knowledge development, they could adopt the artisanal cheese-making model effectively.

\section{Acknowledgements}

This research was funded by the National Research Foundation, South Africa.

\section{Authors' Contributions}

FN, ER, and GE conceptualized and designed the work. FN carried out the literature search, wrote the article and revised it for intellectual content. KD read and commented on the whole text.

\section{Conflicts of Interest Declaration}

The authors declare there is no conflict of interest.

\section{References}

Abdalla, M.O.M., Elsiddig, H.M., Elhaj, N.M. \& Suleiman, T.A., 2013. Chemical and microbiological evaluation of Sudanese braided cheese (Mudaffara). J. Agric. Sci. 21, 253-268.

Abdelgadir, W.S., Hamad, S.H., Moller, P. L. \& Jakobsen, M., 2001. Characterization of the dominant microbiota of Sudanese fermented milk Rob. Int. Dairy J. 11,63-70. DOI: 10.1016/S0958-6946(01)00042-5

Adetunji, V.O., Alonge, D.O., Singh, R.K. \& Chen, J., 2008. Production of Wara, a West African soft cheese using lemon juice as a coagulant. LWT - Food Sci. Technol. 41, 331-336. DOI: 10.1016/j.Iwt.2007.02.012

Agossou Yao, D.A.R., Sprycha, Y., Porembski, S. \& Horn, R., 2015. AFLP assessment of the genetic diversity of Calotropis procera (Apocynaceae) in the West Africa region (Benin). Genet. Resour. Crop Evol. 62, 863-878. DOI: 10.1007/s10722-014-0197-z

Akaichi, F. \& Revoredo-Giha, C., 2014. The demand for dairy products in Malawi. African J. Agric. Resour. Econ. 9, 214225.

Akinyosoye, V., 2006. Demand for dairy products in Nigeria: Evidence From the Nigerian living standards survey. J. Econ. Rural Dev. 16, 13-26.

Aloys, N. \& Angeline, N., 2009. Traditional fermented foods and beverages in Burundi. Food Res. Int. 42, 588-594. doi:10.1016/j.foodres.2009.02.021

Amira, A.M., Besbes, S., Attia, H. \& Blecker, C., 2017. Milk-clotting properties of plant rennets and their enzymatic, rheological and sensory role in cheese making, A review. Int. J. Food Pro. 20, 576-593.

Atasoy, A.F., 2008. Evaluation of pH change kinetics during different stages of kashar cheese production from bovine. J. Food Process. Preserv. 32,416-428.

Awad, S., 2006. Texture and flavour development in Ras cheese made from raw and pasteurized milk. Food Chem. 97, 394-400.

Axtell, B., Fellows, P., Gedi, L,. Lubin, H. \& Musoke, R., 2008. Opportunities in food processing setting up and running. CTA Publishing, Wageningen, Netherlands.

Belli, P., Cantafora, A.F.A., Stella, S., Barbieri, S. \& Crimella, C., 2013. Microbiological survey of milk and dairy products from a small scale dairy processing unit in Maroua (Cameroon). Food Control. DOI:10.1016/j.foodcont.2012.12.021

Bemfeito, R.M., Rodrigues, J. F., Silva, J. \& Abreu, L.R., 2016. Temporal dominance of sensations sensory profile and drivers of liking of artisanal Minas cheese produced in the region of Serra da Canastra, Brazil. J. Dairy Sci. 99,7886-7897. https://doi.org/10.3168/jds.2016-11056

Benkerroum, N., 2013. Traditional fermented foods of North African countries: Technology and food safety challenges with regard to microbiological risks. Comprehensive Reviews in Food Sci. and Safety 12, 54-89. 
Benlahcen, K., Mahamedi, A.E., Djellid, Y., Sadeki, I.F. \& Kihal, M., 2017. Microbiological characterization of Algerian traditional cheese 'Klila'. J. Purity, Utility Reaction and Environment 6, 1- 9.

Bettencourt, E. M. V., Tilman, M., Narciso, V., Carvalho, M. L. S. \& Henriques, P.D.S., 2015. The livestock roles in the wellbeing of rural communities of Timor-Leste. Revista de Economia e Sociologia Rural. 53, 63-80. 10.1590/123456781806-94790053s01005

Beukes, E.M., Bester, B.H. \& Mostert, J.F., 2001. The microbiology of South African traditional fermented milks. Int. J. Food Microbiol. 63,189-197. DOI:10.1016/S0168-1605(00)00417-7

Blundel, P.A.R.K., 2017. Production (cheesemaking process) - 'Artisanal'. The Oxford companion to cheese. Oxford University Press, New York. https://global.oup.com/academic/product/the-oxford-companion-to-cheese9780199330881 ?cc $=$ gb\&lang=en\&\#

Bouma, A., Durham, C.A. \& Meunier-Goddik, L., 2014. Start-up and operating costs for artisan cheese companies. J. Dairy Sci. 97, 3964-72. DOI: 10.3168/jds.2013-7705

Brits, B.M., 2014. Kefalos cheese products: Proudly Zimbabwean. Farmlink, Spring 28-29.

Butler, G., Nielsen, J.H., Larsen, M.K., Rehberger, B., Stergiadis, S., Canever, A. \& Leifert, C., 2011. The effects of dairy management and processing on quality characteristics of milk and dairy products. NJAS 58 (3-4), 97-102. DOI: 10.1016/j.njas.2011.04.00

Calasso, M., Ercolini, D., Mancini, L., Stellato, G., Minervini, F., Di Cagno, R., De Angelis, M. \& Gobbetti, M., 2016. Relationships among house, rind and core microbiotas during manufacture of traditional Italian cheeses at the same dairy plant. Food Microbiol. 54, 115-126. DOI: 10.1016/j.fm.2015.10.008

Chimuti, S., Midzi, N., Njage, P.K. \& Mugadza, D.T., 2016. Microbial species of safety concern in milk from informal processors in Harare, Zimbabwe. Afr. J. Microbiol. Res. 10, 1257-1262.

Cilliers, F.P., Gouws, P.A., Koutchma, T., Engelbrecht, Y., Adriaanse, C. \& Swart, P., 2014. A microbiological, biochemical and sensory characterization of bovine milk treated by heat and ultraviolet (UV) light for manufacturing Cheddar cheese. Innov. Food Sci. Emerg. Technol. 23, 94-106. DOI: 10.1016/j.ifset.2014.03.005

Claeys, W.L., Cardoen, S., Daube, G., De Block, J., Dewettinck, K., Dierick, K., De Zutter, L., Huyghebaert, A., Imberechts, H., Thiange, P., Vandenpla, Y. \& Herman, L., 2013. Raw or heated cow milk consumption: Review of risks and benefits. Food Control 31, 251-262. DOI: 10.1016/j.foodcont.2012.09.035

Commission Regulation, 2005. Microbiological criteria for foodstuff. Regulation No. 2073/2005. Offical J. European Union. Pp 1-26. https://www.fsai.ie/uploadedFiles/Reg2073_2005(1).pdf

Cornelisse, S. \& Hyde., 2017. Get more from your milk: Increasing profit through value-added products. PennState Extension, USA. https://extension.psu.edu/get-more-from-your-milk-increasing-profit-through-value-addedproducts.

Durham, C.A., Bouma, A. \& Meunier-Goddik, L., 2015. A decision-making tool to determine economic feasibility and break-even prices for artisan cheese operations. J. Dairy Sci. 98, 8319-32. DOI: 10.3168/jds.2014-9252

Ejo, M., Garedew, L., Alebachew, Z. \& Worku, W., 2016. Prevalence and antimi-crobial resistance of Salmonella isolated from animal-origin food items in Gondar, Ethiopia. Biomed Res. Int. (article 4290506).

El-Tanboly, E., El-Hofi, M. \& Khorshid, A., 2017. Recovery of cheese whey, a by-product from the dairy industry for use as an animal feed. J. Nutr. Health Food Eng. 6, 148-154.

Eriksson, C. \& Bull, J., 2017. Place-making with goats and microbes: The more-than-human geographies of local cheese in Jämtland, Sweden. J. Rural Stud. 50, 209-217. DOI: 10.1016/j.jrurstud.2017.01.010

FAO, 1990. Importance, technology and economics of traditional milk products. Animal Production and Health Paper 85. Rome, Italy. www.fao.org/3/t0251e/T0251E00.htm\#TOC

FAO, 2018. World Livestock: Transforming the livestock sector through the Sustainable Development Goals. Rome. Pp 222. Licence: CC BY-NC-SA 3.0 IGO. http://www.fao.org/3/CA1201EN/ca1201en.pdf

FAOSTAT, 2020. Livestock processed. http://www.fao.org/faostat/en/\#data/QP

Fox, E., Hunt, K., O'Brie, M. \& Jordan, K., 2011. listeria monocytogenes in Irish farmhouse cheese processing environments. Int. J. Food Microbiol. 145,39-45. DOI: 10.1016/j.jfoodmicro.2010.10.012.

Fox, P.F., Guinee, T.P., Cogan, T.M. \& McSweeney, P.L.H., 2017. Cheese yield. In: Fundamentals of cheese science. Springer, Boston, MA. https://doi.org/10.1007/978-1-4899-7681-9_10

Franz, C.M.A.P., Huch, M., Mathara, J.M., Abriouel, H., Benomar, N., Reid, G., Galvez, A. \& Holzapfel, W.H., 2014. African fermented foods and probiotics. Int. J. Food Microbiol. 190, 84-96. DOI: 10.1016/j.ijfoodmicro.2014.08.033

Gadaga, T.H., Mutukumira, A.N., Narvhus, J.A. \& Feresu, S.B. 1999. A review of traditional fermented foods and beverages of Zimbabwe. Int. J. Food Microbiol. 53,1-11. DOI: 10.1016/S0168-1605(99)00154-3

Gebretsadik, S., Kassa, T., Alemayehu, H., Huruy, K. \& Kebede, N., 2011. Isolation and characterization of Listeria monocytogenes and other Listeria species in foods of animal origin in Addis Ababa, Ethiopia. J. Infect. Public Health. 4, 22-29.

Grobler, S.M., Scholtz, M.M., Bester, J., Mamabolo, J.M. \& Ramsay, K.A., 2008. Dairy production systems in the emerging and communal sectors of South Africa: Results from a structured survey. Appl. Anim. Husb. Rural Dev. $1,25-30$.

Hammad, A.M., Hassan, H.A. \& Shimamoto, T., 2015. Prevalence, antibiotic resistance and virulence of Enterococcus spp. in Egyptian fresh raw milk cheese. Food Control. 50, 815-820. DOI: 10.1016/j.foodcont.2014.10.020

Hattem, H.E., 2012. Effect of pasteurization and season on milk composition and ripening of Ras cheese. J. Brew. Distill. 3,15-22. DOI: $10.5897 / \mathrm{jbd} 11.010$

Holmann, F.J., 2001. Milk market of small scale artisan cheese factories in selected livestock watersheds of Honduras and Nicaragua. Livest. Res. Rural Dev. $13(1), 1-8$.

Hussein, J.B., Suleiman, A.D.S., Ilesanmi, J.Y.O. \& Sanusi, S.A., 2016. Chemical composition and sensory qualities of 
West African soft cheese (warankashi) produced from blends of cow milk and soy milk. Nigerian Journal of Tropical Agriculture 16, 79-89.

Ibrahim, G.A., Sharaf, O.M. \& Abd El-Khalek, A.B., 2015. Microbiological quality of commercial raw milk, Domiati cheese and Kareish cheese. Middle East J. Appl. Sci. 05,171-176.

IFAD (International Fund for Agriculture and Development), 2008. Stories from the field: A cheese making business flourishes in rural Armenia 1-2. http://www.ruralpovertyportal.org/english/ regions/asia/arm/index.htm

Jakobsen, R.A., Heggebø, E.B., Sunde, E.R. \& Skjervheim, M., 2011. Staphylococcus aureus and Listeria monocytogenes in Norwegian raw milk cheese production. Food Microbiol. 28,492-496. DOI: 10.1016/j.fm.2010.10.017

Janhoj, T. \& Qvist, K.B., 2010. The formation of cheese curd. In: B.A. Law \& A.Y. Tamime (eds.) Technology of cheesemaking. Wiley-Blackwell, Ames, IA. Pp. 130-165.

Jerónimo, E. \& Malcata, F., 2016. Abstract. Cheese: Composition and health effects. Ref. Modul. Food Sci. Encycl. Food Heal. 741-747.

Johnson, M.E., 2017. A 100-year review: Cheese production and quality. J. Dairy Sci. 100, 9952-9965. DOI: $10.3168 / j d s .2017-12979$

Kagoro, J.M. \& Chatiza, K., 2012. Zimbabwe's Dairy Subsector Study. Netherlands Development Organization (SNV). https://snv.org/cms/sites/default/files/explore/download/rarp_2016-dairy-subsector-study.pdf

Kees, M. 1994. Cheese production in Benin. AGRIS 28, 26-28. https://agris.fao.org/agrissearch/search.do?recordID=DE94Q0251

Kgatla, S. \& Moremi, R. 2013. Department of Agriculture, Forestry and Fisheries (DAFF) and Food Agriculture Organization (FAO) assist small-holder farmers. Dep. Agric. For. Fish., 2-3.

Khan, M.J., Peters, K.J. \& Uddin, M.M., 2009. Feeding strategies for improving dairy cattle productivity in smallholder farm in Bangladesh. Bangladesh Journal Animal Science 38, 67-85.

Koba, K. \& Yanagita, T., 2014. Health benefits of conjugated linoleic acid (CLA). Obesity Res. Clinical Practice 8(6), e525-532. DOI: 10.1016/j.orcp.2013.10.001

Kunadua, A.P., Holmesb, M., Millerb, E.L. \& Grant, A.J., 2018. Microbiological quality and antimicrobial resistance characterization of Salmonella spp. in fresh milk value chains in Ghana. Int. J. Food Microbiol. 277, 41-49.

Kupiec, B. \& Revell, B. 1998. Speciality and artisanal cheeses today, the product and the consumer. Br. Food J. 100, 236-243.

Laba, S., Arekemase, M. \& Onajobi, I., 2015. Microbiological and proximate analyses of unripened cheese 'Wara' sold in Ilorin environs, Kwara State Nigeria. J. Agric. Res. \& Dev. 14, 23-32.

Lahou, E. \& Uyttendaele, M., 2017. Growth potential of Listeria monocytogenes in soft, semi-soft and semi-hard artisanal cheeses after post-processing contamination in deli retail establishments. Food Control 76,13-23. DOI: 10.1016/j.foodcont.2016.12.033

Licitra, G., Portelli, G., Campo, P., Longombardo, G., Farina, G., Carpino, S. \& Barbano, D.M., 1998. Technology to produce Ragusano cheese: A survey. J. Dairy Sci. 81,3343-3349. DOI: 10.3168/jds.S0022-0302(98)75900-4

López-Expósito, I., Amigo, L. \& Recio, I., 2012. A mini-review on health and nutritional aspects of cheese with a focus on bioactive peptides. Dairy Sci. Technol. 92,419-438. DOI: 10.1007/s13594-012-0066-5

Lundin, J., Dragos lordache, F., Hailu, Y., Kide, M.H. \& Sobhy, N.K., 2015. The production of Cheddar cheese. Introduction to dairy technology. https://www.researchgate.net/publication/282804567

Mapekula, M., Chimonyo, M., Mapiye, C. \& Dzama, K., 2011. Fatty acid, amino acid and mineral composition of milk from Nguni and local crossbred cows in South Africa. J. Food Compos. Anal. 24, 529-536.

Mapiye, C., Chimonyo, M., Muchenje, V., Dzama, K., Marufu, M.C. \& Raats, J.G., 2007. Potential for value-addition of Nguni cattle products in the communal areas of South Africa: A review. Afr. J. Agric. Res. 2, 488-495.

Mattiello, S., Caroprese, M., Matteo, C. G., Fortina, R., Martini, A., Martini, M., Parisi, G., Russo, C., Zecchini, M. \& ASPA Commission, Animal productions in development cooperation projects, 2018. Typical dairy products in Africa from local animal resources. Ital. J. Anim. Sci. 17, 740-754. DOI: 10.1080/1828051X.2017.1401910

McSweeney, P.L.H., Ottogalli, G. \& Fox, P.F., 2004. Diversity of cheese varieties: An overview. Cheese Chem. Phys. Microbiol. 2,1-23. DOI: 10.1016/S1874-558X(04)80037-X

McSweeney, P.L.H., Ottogalli, G. \& Fox, P.F., 2017. Diversity and classification of cheese varieties: An overview. In: P.L.H. McSweeney, P.F. Fox, P.D. Cotter \& D.W. Everett (eds). Cheese. Fourth ed. Academic Press, San Diego. Pp. 781-808.

Mikkelsen, P., 2014. World cheese market 2000-2020. http://pmfood.dk/upl/9735/WCMINFORMATION.pdf

Milk South Africa, 2014. Chapter 1. The MilkSA guide to dairy farming in South Africa. 2nd ed. AgriConnect, South Africa.

Montel, M.C., Buchin, S., Mallet, A., Delbes-Paus, C., Vuitton, D., Desmasures, N. \& Berthier, F., 2014. Traditional cheeses: Rich and diverse microbiota with associated benefits. Int. J. Food Microbiol. 177,136-154. DOI: 10.1016/j.ijfoodmicro.2014.02.019

Muchenje, V., Chimedza-Graham, R., Sikhosana, J.L.N., Assan, N., Dzama, K. \& Chimonyo, M., 2007. Milk yield of Jersey $\times$ Nguni and Jersey $\times$ Tuli F1 and F2 cows reared under smallholder farming conditions. S. Afr. J. Anim. Sci. 8, 7-10.

Mulder, K. \& Wasserfall, R., 2013. Cheeses of South Africa: Artisanal producers and their cheeses. Sunbird, Cape Town.

Musemwa, L., Mushunje, A., Chimonyo, M., Fraser, G., Mapiye, C. \& Muchenje, V., 2008. Nguni cattle marketing constraints and opportunities in the communal areas of South Africa, Review. Afr. J. Agric. Res. 3, $239-245$.

Ndambi, O.A. \& Hemme, T., 2009. An economic comparison of typical dairy farming systems in South Africa, Morocco, Uganda and Cameroon. Trop. Anim. Health Prod. 41, 979-994. DOI: 10.1007/s11250-008-9288-1

Netherlands Development Organization (SNV), 2012. Evaluation of smallholder dairy programmes in Zimbabwe. 
https://snv.org/cms/sites/default/files/explore/download/an_evaluation_of_smallholder_dairy_production_in_zimba bwe.pdf

Nzigamasabo, A. \& Nimpagaritse, A. 2009. Traditional fermented foods and beverages in Burundi. Food Res. Int. 42:588-594. DOI: 10.1016/j.foodres.2009.02.021

Niro, S., Fratianni, P. Tremonte, A., Sorrentino, E., Tipaldi, L., Panfili, G. \& Coppola, R., 2014. Innovative Caciocavallo cheeses made from a mixture of cow milk with ewe or goat milk. J. Dairy Sci. 97 (3), 1296-1304. DOI: 10.3168/jds.2013-7550

Njarui, D.M.G., Gatheru, M., Wambua, J.M., Nguluu, S.N., Mwangi, D.M. \& Keya, G.A., 2011. Consumption patterns and preference of milk and milk products among rural and urban consumers in semi-arid Kenya. Ecol. Food Nutr. 50, 240-262. DOI: 10.1080/03670244.2011.568908

Nosir, S.E., Mahrous, H. \& El-Bagory, A.M., 2014. Enterobacteriaceae in some locally produced cheese, Minufiya Vet. J. 8, 115-123.

Nouani, A., Dako, E. Morsli, A., Belhamiche, N., Belbraouet, S., Bellal, M. \& Dadie, A., 2009. Characterization of the purified coagulant extracts derived from artichoke flowers (Cynara scolymus) and from the fig tree (Ficus carica) in light of their use in the manufacture of traditional cheeses in Algeria. J. Food Technol. 7, 20-29.

O'Connor. C. 1993. Traditional cheesemaking manual. ILCA (International Livestock Centre for Africa), Addis Ababa, Ethiopia.

Omer, I. Hamid, A., Osman, A. \& El Owni, O., 2007. Microbiological properties and sensory characteristics of white cheese (Gibna bayda) Collected in Zalingei Area, West Darfur State. Res. J. Ani. and Vet. Sci. 2, 61-65.

OECD-FAO (Organization for Economic Co-operation and Development-Food and Agriculture Organization of the United Nations), 2015. OECD-FAO Agricultural Outlook 2015, OECD Publishing, Paris, France. http://dx.doi.org/10.1787/agr_outlook-2015-en

OECD-FAO (Organization for Economic Co-operation and Development-Food and Agriculture Organization of the United Nations), 2020. OECD-FAO Agricultural Outlook 2020-2029, 7 Dairy and dairy products. OECD Publishing, Paris, France. https://www.oecd-ilibrary.org/agriculture-and-food/oecd-fao-agricultural-outlook-2020-2029_1112c23b-en

Ombarak, R.A.., Hinenoya, A., Awasthi, S.P., Iguchi, A., Shima, A., Elbagory, A.R.M. \& Yamasaki, S., 2016. Prevalence and pathogenic potential of Escherichia coli isolates from raw milk and raw milk cheese in Egypt. Int. J. Food Microbiol. 221, 69-76. DOI: 10.1016/j.ijfoodmicro.2016.01.009

Omemu, A., Obadina, A, Taiwo, G. \& Obuotor, T., 2014. Microbiological assessment and prevalence of food-borne pathogens in street-vended Wara Nigerian white cheese. Am. J. Food Nutr. 2, 59-62. DOI: 10.12691/ajfn-2-4-2

Ramalho Ribeiro, J.M.C., Horta, A.E.M., Mosconi, C. \& Rosati, A., 2006. Animal products from the Mediterranean area. Wageningen Academic Publishers, The Netherlands. Pp. 170-178.

Ronquest, R., L.-C., Vink, N. \& Sigge, G.O., 2015. Food consumption changes in South Africa since 1994. S. Afr. J. Sci. 111, 1-12. https://doi.org/10.17159/sajs.2015/20140354

Scatassa, M.L., Gaglio, R., Macaluso, G., Francesca, N., Randazzo, W., Cardamone, C., Di Grigoli, A., Moschetti, G. \& Settanni, L., 2015. Transfer, composition and technological characterization of the lactic acid bacterial populations of the wooden vats used to produce traditional stretched cheeses. Food Microbiol. DOI: 10.1016/j.fm.2015.06.008

Scholtz, M.M., Furstenburg, D., Maiwashe, A., Makgahlela, M.L., Theron, H.E. \& van der Westhuizen, J., 2010. Environmental-genotype responses in livestock to global warming: a southern African perspective. S. Afr. J. Anim. Sci. $\quad 40 \quad(5, \quad$ Supplement $\quad 1), 408-413 . \quad$ https://www.sasas.co.za/wpcontent/uploads/2012/09/ScholtzMM40Issue5Congress_0.pdf

Seini, H., Keita, A., Sabiou, M.S., Nafiou, A.M., Maazou, B. A. Sadou, H., Ibrahim, A., Issa, O., Alma, M.M., Sidikou, R.S., Saadou, M., Mogueza, C. \& Mahaman, M.S., 2018. Microbiological characteristics and nutritional quality of traditional Tchoukou cheese from Niger Sabo. Int. J. Curr. Microbiol. App. Sci. 7, 317-328.

Serhan, M., Linder, M., Hosri, C. \& Fanni, J., 2010. Changes in proteolysis and volatile fraction during ripening of Darfiyeh, a Lebanese artisanal raw goat's milk cheese. Small Rumin. Res. 90, 75-82. DOI: 10.1016/j.smallrumres.2010.01.008

Shams, E.A., Yousef, N.S. \& El-Shazly, H.A.M., 2020. Chemical, sensory and rheological evaluation of Karish cheese made by oyster mushroom mycelium. J. Food Dairy Sci. 11, 187-193.

Sharma, P., Segat, A., Kelly, A.L. \& Sheehan, J.J., 2019. Colourants in cheese manufacture: Production, chemistry, interactions and regulation. Compr. Rev. Food Sci. Food Saf. 1, 1-23.

Smit, L.E., Schönfeldt, H.C,. De Beer, W.H.J. \& Smith, M.F., 2001. The influence of factory and region on the composition of South African Cheddar and Gouda cheese. J. Food Compos. Anal. 14, 177-198. DOI: 10.1006/jfca.2000.0973

Terzic-Vidojevic, A., Vukasinovic, M,. Veljovic, K,. Ostojic, M, \& Topisirovic, L., 2007. Characterization of microflora in homemade semi-hard white Zlatar cheese. Int. J. Food Microbiol. 114, 36-42. DOI: https://pubmed.ncbi.nlm.nih.gov/17182146/

Vazquez-Fontes, C., Sanchez-Vera, E. Castelan-Ortega, O. \& Espinoza-Ortega, A., 2010. Microbiological quality of artisan-made Mexican Botanero cheese in the Central Highlands. J. Food Safety 39, 40-50. https://doi.org/10.1111/j.1745-4565.2009.00188.x

Walther, B., Schmid, A., Sieber, R. \& Wehrmuller, K., 2008. Cheese in nutrition and health. Dairy Sci. Technol. 88, 389405.

Yunusa, A. J., 2011. Quality characteristics of cheese produced from three breeds of cattle in Nigeria. J. Enviro. and Agri. in Developing Countries 3, 95-99.

Yunusa, I., Gumel, A.M., Adegbusi, K. \& Adegbusi, S., 2012. School feeding program In Nigeria: A vehicle for nourishment of pupils. J. African Educ. Res. Netw. Sch. 12, 30-35. 